\title{
Thermodynamic interpretation of Na-K-Ca geothermometer in the natural water system
}

\author{
NaOtatsu Shikazono \\ Geological Institute, Faculty of Science, \\ University of Tokyo, Hongo, Tokyo 113, Japan
}

(Received January 29, 1976)

\begin{abstract}
A cation-chloride concentration diagram showing the stability of minerals in natural water system at elevated temperatures is constructed. The curves on this diagram showing the equilibrium between aqueous solution and minerals commonly occurring in nature generally satisfy the empirical Na-K-Ca relationship obtained by FOURNIER and TRUESDELL (1973). This indicates that the chemical composition of natural waters is largely controlled by minerals commonly occurring in nature.
\end{abstract}

\section{INTRODUCTION}

It has been well known that the atomic $\mathrm{Na} / \mathrm{K}$ ratio in natural waters is related to temperature (WhITE, 1965, 1968; Ellis, 1969, 1970). This relationship has been also experimentally obtained (ORVILLE, 1963; Ellis and MaHON, 1967; Hemley, 1967). This is interpreted by albite-K feldspar-aqueous solution equilibrium(WHITE, 1965; ELLIS, 1970; FOURNIER and TRUESDELL, 1973). Recently, FouRNIER and TRUESDELl (1973) showed that the ratio $\mathrm{Na} / \mathrm{K}$ of solution generally yields the temperature much higher than actual temperature and in addition to the concentrations of $\mathrm{Na}$ and $\mathrm{K}$ the concentration of $\mathrm{Ca}$ has to be considered in order to estimate the temperature of natural water. They called the relationship of the concentrations of $\mathrm{Na}, \mathrm{K}$ and $\mathrm{Ca}$ with temperature "Na-K-Ca geothermometer".

In the present paper, it is attempted to interpret the Na-K-Ca geothermometer thermodynamically on the basis of mineral-water equilibrium.

\section{Thermodynamic Calculation and Discussion}

It is common in the natural water system that $\mathrm{Na}^{+}$constitutes the most dominant cation. Among anions, $\mathrm{Cl}^{-}$and $\mathrm{HCO}_{3}^{-}$are dominant in general. At elevated temperatures considered in the present paper, $\mathrm{pH}$ is generally less than seven as will be deduced later. In this $\mathrm{pH}$ range $\mathrm{H}_{2} \mathrm{CO}_{3}$ is considered on the basis of its dissociation constant (RYZHENKO, 1963) to be contained in the solution more than $\mathrm{HCO}_{3}^{-}$. Therefore, the concentration of $\mathrm{HCO}_{3}^{-}$is assumed to be neglected in comparison with $\mathrm{Cl}^{-}$. Thus the following electroneutrality relation is approximately established in the aqueous solution.

$$
m_{\mathrm{Na}^{+}} \doteqdot m_{\mathrm{Cl}^{-}}
$$

where $m$ is molality.

HELGESON (1967) constructed activity diagram depicting chemical equilibrium among minerals and aqueous solution at elevated temperatures (Fig. 1). At three phase equilibrium points (albite-sericite-K feldspar and albite-sericite- $\mathrm{Na}$ montmorillonite) of $\mathrm{Na}_{2} \mathrm{O}-\mathrm{K}_{2} \mathrm{O}-\mathrm{SiO}_{2}-\mathrm{Al}_{2} \mathrm{O}_{3}-\mathrm{H}_{2} \mathrm{O}$ system at elevated temperatures (Fig. 1),

$$
a_{\mathrm{Na}^{+}} / a_{\mathrm{H}^{+}}=\text {constant }
$$

For these points, the relation between $\mathrm{pH}$ and the concentration of $\mathrm{Cl}^{-}$can be derived from equations (1) and (2). Thermochemical data were taken from HELGESON (1969) for the construction of the diagram. Figure 2 shows that silicate mineral assemblages comprise $\mathrm{pH}$ buffer system and $\mathrm{pH}$ decreases with increasing concentration of $\mathrm{Cl}^{-}$.

In the similar manner described above, the relation between the concentrations of $\mathrm{K}^{+}$and $\mathrm{Cl}^{-}$is derived (Fig. 3). In this case, $\log m_{\mathrm{K}^{+}}$ increases with increasing $\log m_{\mathrm{Cl}^{-}}$.

If calcite is in equilibrium with the aqueous solution, the relation between $\mathrm{pH}$ and the concentration of $\mathrm{Ca}^{2+}$ can be obtained from the 


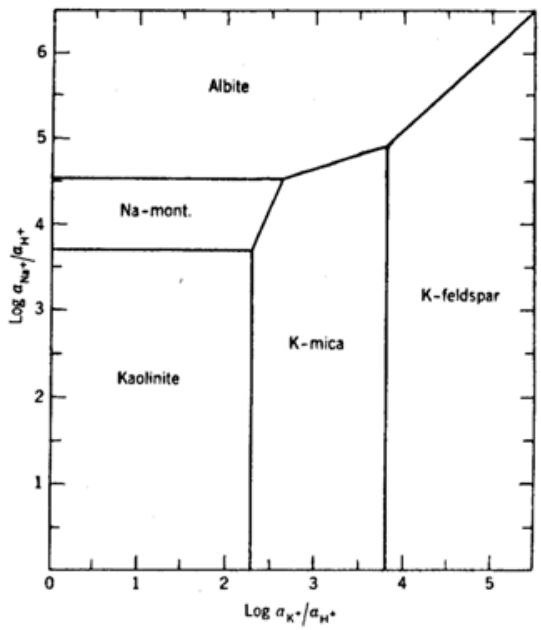

Fig. 1. Activity diagram depicting chemical equilibrium among minerals and aqueous solution at $300^{\circ} \mathrm{C}$ (after HELGESON, 1967). The activity of water is taken as unity. Quartz is present.

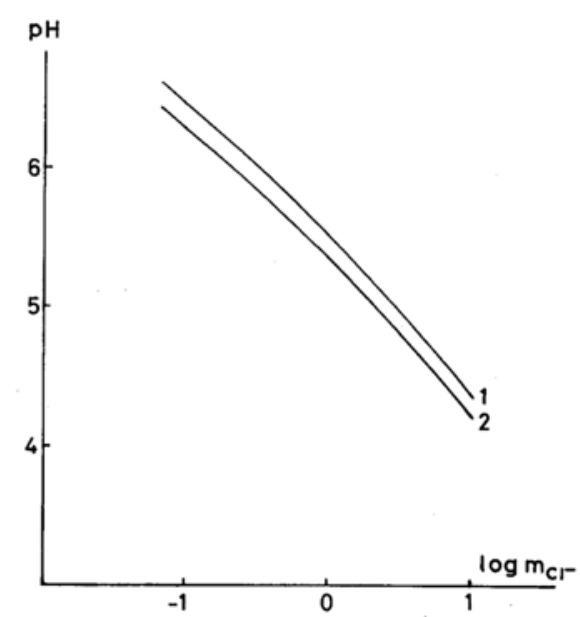

Fig. 2. The variation of $\mathrm{pH}$ with concentration of $\mathrm{Cl}^{-}$ in aqueous solution in equilibrium with the silicate mineral assemblages at $250^{\circ} \mathrm{C}$.

1: Albite-sericite-Na montmorillonite-quartz

2: Albite-sericite-K feldspar-quartz

following equilibrium.

$$
\mathrm{CaCO}_{3}+2 \mathrm{H}^{+}=\mathrm{Ca}^{2+}+\mathrm{H}_{2} \mathrm{CO}_{3}
$$

The equilibrium constant for this reaction is expressed as,

$$
\mathrm{K}=a_{\mathrm{Ca}^{2+}} \cdot a_{\mathrm{H}_{2} \mathrm{CO}_{3}} / a_{\mathrm{H}^{+}}^{2}
$$

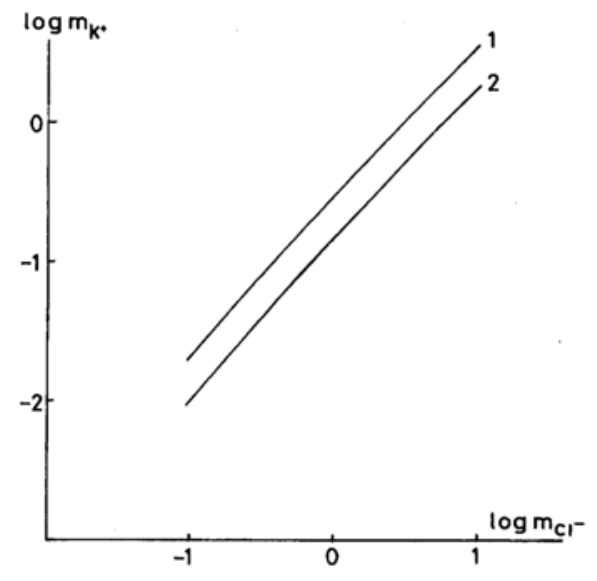

Fig. 3. The variation of concentration of $\mathrm{K}^{+}$with that of $\mathrm{Cl}^{-}$in aqueous solution in equilibrium with the silicate mineral assemblages at $250^{\circ} \mathrm{C}$.

1: Albite-sericite-Na montmorillonite-quartz

2: Albite-sericite-K feldspar-quartz

This equation shows that activity of $\mathrm{Ca}^{2+}$ is related to $\mathrm{pH}$, concentration of $\mathrm{H}_{2} \mathrm{CO}_{3}$ and temperature. Because $\mathrm{pH}$ is related to the concentration of $\mathrm{Cl}^{-}$for the equilibrium curves 1 and 2 in Fig. 2, the relation between the concentrations of $\mathrm{Ca}^{2+}$ and $\mathrm{Cl}^{-}$can be derived for calcite-albite-sericite-K feldspar-quartz (curves 4 7 in Fig. 4) and calcite-albite-sericite-Na montmorillonite-quartz equilibrium (curves 5 and 8 in Fig. 4) with constant $m_{\mathrm{H}_{2} \mathrm{CO}_{3}}$. The range of $m_{\mathrm{H}_{2} \mathrm{CO}_{3}}$ in the solution in equilibrium with calcite is assumed to be $10^{-2}$ to $10^{-1}$. The other equilibrium curves for the assemblage including $\mathrm{Ca}$ minerals are also drawn (Fig. 4). These assemblages are wairakite-albite-sericite-K feldsparquartz (curve 3), Ca montmorillonite-albitesericite-Na montmorillonite-quartz (curve 6), Ca montmorillonite-albite-sericite-K feldspar-quartz (curve 9) and anhydrite (curve 10). The effect of solid solution on the equilibrium curves is not considered because of the lack of thermochemical data of solid solution.

FOURNIER and TRUESDELL (1973) showed that $\log m_{\mathrm{Na}^{+}} / m_{\mathrm{K}^{+}}+4 / 3 \log m_{\mathrm{Ca}^{2}}{ }^{+} / m_{\mathrm{Na}^{+}}{ }^{+}$is constant at constant temperature over $100^{\circ} \mathrm{C}$. This value is about 0.8 at $250^{\circ} \mathrm{C}$.

$$
\log m_{\mathrm{Na}^{+}} / m_{\mathrm{K}}+4 / 3 \log m_{\mathrm{Ca}^{2+}}{ }^{2+} m_{\mathrm{Na}^{+}}=0.8
$$

Substitution of $m_{\mathrm{Na}^{+}}$for $m_{\mathrm{Cl}^{-}}$can be approximately made. The concentration of $\mathrm{K}^{+}$is expressed as a function of that of $\mathrm{Cl}^{-}$(Fig. 3). 


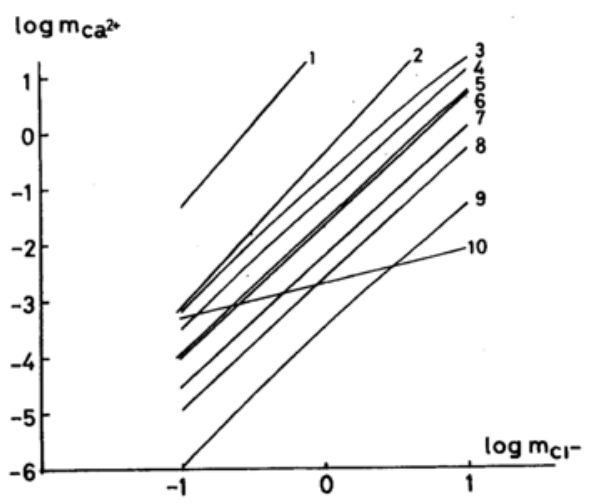

Fig. 4. The variation of concentration of $\mathrm{Ca}^{2+}$ with concentration of $\mathrm{Cl}^{-}$in aqueous solution in equilibrium with a given mineral assemblage at $250^{\circ} \mathrm{C}$.

1: Equilibrium curve based on albite-sericite-Na montmorillonite-quartz-aqueous solution equilibrium and $\mathrm{Na}-\mathrm{K}-\mathrm{Ca}$ relationship obtained by FOURNIER and TRUESDELL (1973).

2: Equilibrium curve based on albite-K feldspar-aqueous solution equilibrium and $\mathrm{Na}-\mathrm{K}$-Ca relationship obtained by FOUNIER and TRUESDELL (1973).

3: Wairakite-albite-sericite-K feldspar-quartz.

4: Calcite-albite-sericite- $\mathrm{K}$ feldspar-quartz $\left(\mathrm{m}_{\mathrm{H}_{2} \mathrm{CO}_{3}}=\right.$ $10^{-2}$ ).

5: Calcite - albite - sericite - Na montmorillonite - quartz $\left(m_{\mathrm{H}_{2} \mathrm{CO}_{3}}=10^{-2}\right)$.

6: Ca montmorillonite-albite-sericite-Na montmorillonite -quartz.

7: Calcite-albite-sericite- $\mathrm{K}$ feldspar-quartz $\left(\mathrm{m}_{\mathrm{H}_{2} \mathrm{CO}_{3}}=\right.$ $10^{-1}$ ).

8: Calcite - albite - sericite- $\mathrm{Na}$-montmorillonite - quartz $\left(\mathrm{m}_{\mathrm{H}_{2} \mathrm{CO}_{3}}=10^{-1}\right)$.

9: $\mathrm{Ca}$ montmorillonite-albite-sericite- $\mathrm{K}$ feldspar-quartz 10: Anhydrite $\left(\mathrm{mSO}_{4}^{2-}=10^{-3}\right)$.

Therefore, the empirical relation obtained by FOURNIER and TRUESDELL (1973) is changed into,

$$
\begin{gathered}
\log m_{\mathrm{Ca}^{2+}=} 2 \log m_{\mathrm{Cl}^{-}}+6\left(\log \gamma_{\mathrm{Na}^{+}} /\right. \\
\left.\gamma_{\mathrm{K}^{+}}\right)+\mathrm{k}
\end{gathered}
$$

where $\mathrm{k}$ is -0.9 and 1.0 for albite- $\mathrm{K}$ feldspar and albite-sericite-Na montmorillonite-quartz equilibrium, respectively and $\gamma_{\mathrm{i}}$ denotes activity coefficient of $i$ species. These curves are drawn in Fig.4. The slopes of the curves of 1 and 2 are nearly the same as those of the other curves calculated.

It is very notable that curves for the common mineral assemblages at elevated temperatures (calcite - albite - sericite - $\mathrm{K}$ feldspar-quartz
$\left(m_{\mathrm{H}_{2} \mathrm{CO}_{3}}=10^{-2}\right)$ and wairakite-albite-sericite- $\mathrm{K}$ feldspar-quartz assemblage) are close to the curve 2 in position. To the contrary, the curve for the mineral assemblage, albite-sericite-Na montmorillonite-quartz, derived from the Na-K-Ca relationship obtained by FourNIER and TRUESDELL (1973) is quite different in position from the other curves calculated and the $\mathrm{Ca}^{2+}$ concentration in the solution in equilibrium with this mineral assemblage is higher than $\mathrm{Na}^{+}$concentration under high salinity conditions.

In conclusion, these results indicate that the chemical composition of natural water at $250^{\circ} \mathrm{C}$ is largely controlled by such minerals commonly occurring in nature as albite, $\mathrm{K}$ feldspar, sericite, calcite, wairakite and quartz.

Limited condition is treated in the present paper. Wider physicochemical and geologic environments have to be treated in order to interpret precisely the natural water composition.

Acknowledgments-I am indebted to Dr. Y. KaJIWARA, Tokyo University of Education, for his critical discussions and suggestions.

\section{REFERENCES}

E LLIS, A. J. and MAHON, W. A. J. (1967) Natural hydrothermal systems and experimental hot water/ rock interactions. Geochim. Cosmochim. Acta 28, 1323-1357.

ELLIS, A. J. (1969) Present-day hydrothermal systems and mineral deposition. Ninth Commonwealth Mining and Metallurgical Congress, Mining and Petroleum Geology Sect. Paper 7, 30 pp.

ELLIS, A. J. (1970) Quantitative interpretation of chemical characteristics of hydrothermal systems. Proceedings United Nations Symp. on the Development and Utilization of Geothermal Resources, Risa, 1970, 2, Part 1, Geothermics, Spec. Issue 2, 516528.

FourNiER, R. O. and TRUESDELl, A. H. (1973) An empirical $\mathrm{Na}-\mathrm{K}-\mathrm{C}$ a geothermometer for natural waters. Geochim. Cosmochim. Acta 37, 1255-1275.

HELGESON, H. C. (1967) Solution chemistry and metamorphism. Researches in geochemistry (D. H. AbELSON, ed.), Wiley, New York v.2. 362404.

HeLGeSON, H. C. (1969) Thermodynamics of hydrothermal systems at elevated temperatures and pressures. Am. J. Sci. 276, 729-804.

HEMLEY, J. J. (1967) Aqueous $\mathrm{Na} / \mathrm{K}$ ratios in the system $\mathrm{K}_{2} \mathrm{O}-\mathrm{Na}_{2} \mathrm{O}-\mathrm{Al}_{2} \mathrm{O}_{3}-\mathrm{SiO}_{2}-\mathrm{H}_{2} \mathrm{O}$ (abstract). Program, 1967 Annual Meeting, Geol. Soc. Am. New 
Orleans, Louisiana. 94-95.

ORVILLE, P. N. (1963) Alkali ion exchange between vapor and feldspar phases. Am. J. Sci. 261, 201237.

RYZHENKO, B. N. (1963) Determination of dissociation constants of carbonic acid and the degree of hydrolysis of the $\mathrm{CO}_{3}^{2-}$ and $\mathrm{HCO}_{3}^{-}$ions in solutions of alkali carbonates and bicarbonates at elevated temperatures. Geochemistry No.2, 151-164.
WHITE, D. E. (1965) Saline waters of sedimentary rocks. Fluids in subsurface environments - A symposium. Am. Assoc. Petrol. Geol. Mem.4, 342-366.

WHITE, D. E. (1968) Environments of generation of some base metal ore deposits. Econ. Geol. 63, 301335 . 